\title{
溶接現象の可視化技術
}

\section{Imaging Analysis of Welding Phenomena}

\section{小川洋司*}

Yoji OGAWA

Key Words: Arc, Imaging, Spectrum, Plasma, Recombination, High-speed camera

\section{1. 緒 言}

アークやレーザを熱源として使用する溶接、切断、溶射 などの熱加工技術は、素材から製品の組み立てに至るもの づくりの中核として、あらゆる製造業分野に浸透し活用さ れている。また、アークやレーザを光源として使用する技 術も、ほとんどの製品製造業分野でリソグラフィ、スポッ トキュア、表面改質などに用いられ、あるいは液晶プロジェ クタや電子顕微鏡などの光源として非常に広い範囲で利用 されている。これらのプロセスは数ミリメートルという狭 い領域で、固相－液相－気相－プラズマの 4 つの状態が混 相して干渉し合う複雑な高温プロセスであり、科学的に十 分に理解されていない側面もある。近年の可視化観察技術 と数值計算シミュレーション技術の進展により目覚ましい 発展により定量的な理解が進展している ${ }^{1,2)}$ 。しかしながら、 詳細な現象の解明によりそのプロセスの複雑性がより明瞭 になったことにより、さらなる疑問が生じている側面も見 逃せない。

本論では、今後の研究の進展の一助となることを期待し、 筆者が従事してきた溶接現象の可視化技術について、学会 誌ではあまり取り上げられてこなかった観点で整理した結 果を紹介する。

\section{2. 視ることと撮影すること}

「視る」とは、科学技術や芸術などの分野を問わず、眼に 入ってきた対象の全体像と特に注意すべき特定領域の微細 な変化を見逃さずに理解し判断すること、対象の本質に触 れることと考えられる。視た結果の判断過程では、個人の 身体能力などの属人的な特性と周囲の文化環境に依拠する 部分が大きく影響する。例えば交通信号の進めが青色か緑 色かの定義の問題のように、視た結果の判断をその判断過 程とともに他者に理解させるためには、用いる言語定義の 明確化から論理判断プロセスの説明まで、個々の属する文 化の差異までを明確に理解して言語化しなければならず、
暗黙知の定量化と同様な困難がある。

一方、「撮影する」ことは空間的な対象を 2 次元平面に 写像して記録し必要に応じて再生することにより、時間と 空間を超えて複数の関係者が情報を共有でき、直感的な理 解が容易であるという特徴を有している。視て判断した結 果を言語情報に変換する必要はないが、撮影する対象その ものは空間的に広がるとともに時間的に変動することが多 い。また色 (分光波長) 情報とその強度特性が多岐にわたっ ているため、撮影意図・目的と撮影機材及び撮影者の能力 に依存する側面がある。通常のカメラとモニタは人が見た 周囲の映像をできるだけ人の感覚に違和感を生じさせない ように取得して表示することを目的としている。一方、アー クやレーザ溶接においては、離散的な波長の光が主要な構 成要素であり、かつ対象の輝度差が大きいという特殊な環 境であるために、撮影には注意が必要となる。このような 場合には、同じ対象を撮影しても、その撮影した結果を見 た人が全く異なる印象を持つこともそう珍しいことではな い。また、錯視や思い込みによる誤解を生じやすい対象で もあり、映像の定量化による解析も重要となる。科学技術 的理解を対象とした撮影の場合には、客観性と再現性が最 も重要な要素の一つとなるため、撮影意図も含めて対象状 態と用いた機材の性能などについての詳細な記述とともに 取得した映像の值域と定義域を明確に認識した定量化が重 要となる。Fig.1にSUS304 及び軟鋼を母材として、アルゴ ン雲囲気で $100 \mathrm{~A}$ の静止アークを通電した状態を水平方向 から撮影した結果の例を示す。撮影には市販の一眼レフデ ジタルカメラを用い、望遠レンズと接写リングを組み合わ せ所定の拡大率とし、ND フィルタで減光したうえで絞り と露光時間を調整して撮影している。露光時間のみを約 10 倍づつ変化させて撮影した例であり、左端の最も露光時間 の長い撮影結果では、電極と母材部分は明瞭に観察できる が、アークの部分はほぼ飽和している。中央の映像は露光 時間を $1 / 9$ にした撮影結果であり、母材表面の状況が明瞭 に識別できるが、電極先端部近傍とタングステン電極全体

*(独)産業技術総合研究所 四国センター（７ 761-0395 香川県高松市林町 2217-14）

National Institute of Advanced Industrial Science and Technology (2217-14 Hayasi -chou, Takamatsu, Kagawa, 761-0395 Japan) 
の状況が認識しにくい例である。右端の映像は露光時間が 左端の $1 / 100$ の例であり、電極先端部近傍の状況が明確に 認識でき、母材表面のプラズマ状態が観察できる。一般的 にアーク現象の撮影では、左端のような多くの情報が失わ れた露出オーバーの映像が視覚的に受け入れやすいために 良く利用される。しかし、このような映像は肝心のアーク 部の情報が欠如するため、現象の解析を十分に行えないこ とがある。

上側の SUS304のアークと下側の軟鋼のアークは全く同 一の撮影条件の映像であり、両者を比較すると以下のこと が分かる。

(1)アークは電極先端部で発生し、中間領域までは下方 に近づくに伴いやや広がり、母材表面近くでプラズマ気流 が横方向に広がるためアークの発光領域が横に広がる釣鐘 状の分布となる。（2）母材表面近傍では急速に半径が小さ くなりアーク光がほとんど観測されない間隙が存在する。 (3) 軟鋼上へのアークの方が電極は若干明るく撮影されて おり電極温度が高いと推察できる。(4) 母材表面に青白く 光る領域が存在し、SUS304の場合には広く広がり、軟鋼 の場合には直径 $1 \mathrm{~mm}$ 程度の中央部の若干盛り上がった領 域で発生している。この青白い光の波長はその他の実験結 果から波長が $500 \mathrm{~nm}$ 近傍の光であることが分かっている。 (5) 電極先端部近傍にも青白く光る領域が存在し母材表面 より青みがかり波長が短くその他の実験結果から波長が $480 \mathrm{~nm}$ 近傍の光であることが分かっている。

異なる母材に対するアークの定性的な比較は、撮影条件 にはあまり影響されず両者の差異を認識できる。一方、露 光時間が異なる 3 枚の映像を予備知識抜きで視た場合、同 じ現象を撮影した映像と即断するのは難しい。

市販のカメラは人間の感覚にあわせて、暗いところから 明るいところまで比較的広い輝度範囲の映像をカバーし、 特に極端に明るい輝度の映像もハレーションを起こしにく いように調整されている。このため、撮影結果の輝度と実 際の撮影対象の輝度とは直線関係にない場合が多く、定量 的な解析には注意が必要となる。また、通常は 8 ビット 256 階調) で記録されるため、数值の精度についても注意が 必要となる。さらに、自然界の連続的に変化する光波長で 自然な映像となるように撮像素子が選定されているため、 アークのように離散的な波長の光を撮影する場合、機種に より色調が大きく変化することが多い。

特徵や差異の対比という観点からは、撮影すること＝可 視化は非常に重要な技術となっている。近年の観察・計測 機器の急激な進歩により安価で高性能な機種の利用が容易 となっている。特に高速度ビデオの高機能化は著しく、電 圧・電流などの信号より高速度で記録できるまでになって いる。高精細化により 1 枚の画像の画素数が増加し、ビデ オの高速度化により画像の枚数が増加し、さらに 8 ビット のデータから 10-12 ビットへと高深度化も進展し取り扱う
データ量が爆発的に増加してきた。これらの膨大なデータ の利用と解析についても工夫が必要となってきている。

\section{3. アークの特徵とその観察}

アーク溶接では、陰極と陽極の間でアーク放電を持続さ せ、そのエネルギーを有効に活用して母材を溶融・凝固さ せて部材の一体化を行う。アーク溶接は一見単純なプロセ スと見えるが、実際には「電極ーアークプラズマー溶融金 属一母材」という非常に狭い領域で極端に温度の異なる状 態が存在し、なおかつ多くの微量元素が高温の物理・化学 反応に寄与する非常に複雑なプロセスとなっている。

アークプラズマは、ガス温度が十分高くなり電子温度に ほぼ等しい熱平衡状態になっている場合が多い。プラズマ 内部は無数の分子、原子、イオン、電子などの構成粒子が 励起、解離、電離とエネルギー状態を変化させながら相互 に衝突を繰り返している。熱平衡状態にあるということは、 構成粒子の組成や運動及び励起、解離、電離に至るあらゆ る属性が統計的に処理でき、一つの温度で記述できること を意味している。換言すると、アークプラズマの熱力学 · 輸送特性が得られ、これを連続の式、運動量保存式、エネ ルギー保存式、成分保存式を連立させてアークプラズマの 状態、たとえば温度、導電率、入力・放射パワーなどの空 間分布および過渡変化などを定量的に推定できる ${ }^{3)} 。$

アークプラズマは、超高温というだけでなく高輝度とい う特徵を持つ。この高輝度な放射エネルギーは、紫外線か ら赤外線まで幅広く放射が可能であり、溶接だけでなく、 殺菌、大規模照明、赤外線加熱、リソグラフィ、スポットキュ ア、表面改質等、さまざまな用途に応用が広がっている。

放射特性は、主にプラズマ中の電子挙動により決定され、 線スペクトルや連続スペクトルが放射される。原子やイオ ンが取りうるエネルギー準位は、核外電子の配置により決 まる。このエネルギー準位間の遷移により放射・吸収が生 じ、各元素固有のスペクトルが現れる。陰極から放出され た電子がプラズマ中で基底状態の原子に衝突し、原子がエ ネルギーの高い励起状態に遷移する。励起状態から基底状 態、または準安定状態に戻るときにこのエネルギー差分だ け放射されたものが輝線スペクトルである ${ }^{3)} 。$

$$
\begin{aligned}
\lambda= & \mathrm{hc} /\left(\mathrm{E}_{\mathrm{e}}-\mathrm{E}_{\mathrm{g}}\right) \\
& \mathrm{E}_{\mathrm{e}} \text { : 励起状態のエネルギー } \\
& \mathrm{E}_{\mathrm{g}}: \text { 基底状態または準安定状態のエネルギー } \\
& \mathrm{h}: \text { プランク定数 }\left(6.63 \times 10^{-34} \mathrm{~J} \cdot \mathrm{s}\right) \\
& \mathrm{c}: \text { 光速度 }\left(2.998 \times 10^{8} \mathrm{~m} / \mathrm{s}\right)
\end{aligned}
$$

線スペクトルと異なり、広い波長範囲で連続的な強度分 布を持つものが連続スペクトルである。連続スペクトルは 再結合放射および制動放射により生じる。プラズマ中で電 子とイオンが衝突により再結合し、電子の運動エネルギー に見合うエネルギーが連続スペクトルとして放射される。 その波長 $\lambda$ は (3.2) 式で示される ${ }^{3)}$ 


$$
\begin{aligned}
\lambda= & \mathrm{hc} /\left(\mathrm{eV}_{\mathrm{i}}+\mathrm{K}\right) \\
& \mathrm{eV}_{\mathrm{i}}: \text { 電離エネルギー } \\
& \mathrm{K}: \text { 電子の運動エネルギー }
\end{aligned}
$$

制動放射は、自由電子が周囲の局所電界の影響でエネル ギーが小さくなる時に、そのエネルギーの差を放射する光 である。アルゴンの放射係数は、15,000 K まで急激に増加 し、アーク中心部の温度域である $15,000 \mathrm{~K} \sim 30,000 \mathrm{~K}$ では 増加は緩やかになり、最大で $10^{9} \mathrm{~W} /\left(\mathrm{m}^{3} \cdot \mathrm{sr}\right)$ 程度の值になる。 連続スペクトルでは再結合放射が支配的であるが、30,000 $\mathrm{K}$ の高温では制動放射の割合も無視できない。

高温となる電極や溶融池からは連続光である光（熱）放 射が存在する。また、酸化タングステンの溶融温度（1,073 K）及び蒸発温度 $(1,803 \mathrm{~K})$ は通常の TIG 溶接における夕 ングステン電極先端温度である $3000 \mathrm{~K}$ 程度よりかなり低 く、シールド条件が適切でないと電極側面部より蒸発が生 じ、蒸発した酸化粒子はプラズマ空間内で解離し、電極側 面部で結晶化して付着する。

Fig.2にヘリウムをシールドガスとして用い、水冷銅板上 及び SUS304 上に $100 \mathrm{~A}$ の静止アークを発生させたときの 映像例を示す。ND フィルタと絞り（f19）を一定にして、アー ク発生の約 10 秒後に露光時間のみを変化させて連続的に撮 影した映像である。カメラの露光時間と絞りは露光量が 2 倍刻みで変化するよう設定されており、実際には溶接条件 ごとに 18 種類程度の映像を取得しているが、見た目の変 化を分かりやすく表示するために、4 倍刻みの映像を 4 種 類表示している。水冷銅板上のアークプラズマ部はへリウ ムの励起・電離に起因する発光のみとなる。一方 SUS304 上のアークでは母材である SUS304 から蒸発する金属成分 に起因する発光が大きく影響する。金属の電離電圧はへリ ウムに比較して極めて小さく、3,000-9,000 K の低温プラ ズマ中では金属成分のみが選択的に電離し、プラスの電荷 を有する金属イオンは電極方向に吸引される ${ }^{4,5)}$ 。金属イオ ンの一部はタングステン電極近傍で電子と再結合して発光 し、またある金属イオンは電極に衝突して電極の発光に寄 与する。詳細については後述するが、電極表面およびその 近傍の空間では電極温度に依存して酸化還元反応や蒸発及 び解離など複雑な反応が生起しており、アークの条件によ り電極表面の発光状態も変化している。

Fig.3にシールドガス成分がアークプラズマに及ぼす例 を示す。シールドガスとして、純アルゴン、純ヘリウム及 びアルゴンとヘリウムの混合ガスを用いて撮影した結果を 示す。撮影はカラーの高速度ビデオと $694 \mathrm{~nm}$ の干渉フィ ルターを用いた白黒カメラ及び白黒カメラレンズの先端に 分光プリズムを装着して電極中心軸上のスペクトル分布を 撮影した結果の 3 種類の映像を示す。各カメラの撮影条件 は同一にし、明るさの定量的な比較を可能にしている。カ ラーの映像は RGB 各 8 ビット（256 階調）、白黒カメラに ついては 10 ビット（1024 階調）のデータとなっている。
スペクトル映像については強度の定量的比較を行うため に疑似カラー表示をしており、色と輝度との対応は各図左 端のカラーバーに示した ${ }^{6}$ 。 アルゴンシールドではプラズ マ空間全体に $400 \mathrm{~nm}$ から $850 \mathrm{~nm}$ の波長範囲の連続スペ クトルと多数の特性スペクトルが存在している。一方、へ リウムシールドではプラズマ空間には少数のへリウム原子 スペクトルが存在し連続スペクトルはほとんど観察されな い。電極表面部では再結合による強い連続スペクトルが観 察される。電極先端部の温度は $3,000 \mathrm{~K}$ 程度であり、この 温度領域で最大強度となる光放射波長は $950 \mathrm{~nm}$ 程度とな る。放射波長が $800 \mathrm{~nm}$ を超える近赤外領域ではカメラの 感度特性が劣化するため断定はできないが $850 \mathrm{~nm}$ 以上の 近赤外領域で連続スペクトルがほとんど観察されていない ことから、この連続スペクトルは、電極表面部近傍で頻繁 に生じている電離と再結合に起因すると考えられる。アル ゴンとヘリウムの構成比が 1 対 3 のシールド条件では、電 離電圧の高いヘリウムの特性スペクトルはプラズマ温度の 高い領域のみに認められ、アルゴンスペクトルが主となっ ている。694 nm はアルゴン原子線の波長であり、純アルゴ ンシールドの場合にはアークは比較的緊縮しているのに対 して、アルゴンとへリウムを混合した場合には比較的横方 向に広がった形状を示す。

Fig.4に同じカラーカメラにさまざまなフィルタを装着し て撮影した結果を示す。シールドガスには流量 $15 \mathrm{~L} / \mathrm{min} の$ ヘリウムガスを用い、静止した状態で SUS304に100 A の アークを発生させ、アーク発生 10 秒後の時点で撮影した。 上段の映像はNDフィルタで撮影した映像と、その映像の 各色成分を分離して表示している。以後は電極を再研磨せ ずにそのまま用い、母材とフィルタを交換して、アーク発 生 10 秒後から露光時間を変化させて連続的に撮影した映像 のうち、輝度が飽和していない撮影条件の映像例を示して いる。中段及び下段の映像では、電極先端付近で明るい帯 状の領域が存在しているが、これは電極表面でタングステ ンのデンドライト結晶が存在している領域であり、タング ステン原子が結晶表面に衝突付着して凝固する際に放射さ れる光と考えられる。

一方、(j) $532 \mathrm{~nm}$ の映像に電極先端から半径約 $1 \mathrm{~mm} の$ 球面上に明るく光る領域が存在し、この領域がちょうど電 極の明るい領域と交差しておりこの影響も無視できない。 Fig.3で示したスペクトル映像と同様に $632 \mathrm{~nm}$ と $694 \mathrm{~nm}$ の映像で電極全体が明るく撮影されている。 SUS304上の アークの場合には水冷銅板上のアークと異なり、溶融池が 存在しその中心部表面に母材から蒸発した金属成分による 発光が存在する。電極の平行部と先端の円錐状の境界付近 （以後この領域を電極ショルダー部と呼ぶ）から明るい光の 金が存在しており、この傘の境界付近が金属粒子がイオン 化する約 $3,000 \mathrm{~K}$ 程度の領域と考えられ、金属イオンが電 極と衝突し冷却される過程での発光が電極ショルダー部近 
傍での青白い光と考えられる。シミュレーションの検証な どではアノード部での主たる電流流路の大きさを確定する ことが重要となるが、(f) $458 \mathrm{~nm}$ の映像で観察される直径 約 $1 \mathrm{~mm}$ の明るい領域がその候補となる。

Fig.5 にシールドガスの構成比がプラズマ形状及び電極 輝度に及ぼす影響を示す。母材の金属成分の影響を除去す るために水冷銅板上のアークを比較している。アーク長 3 $\mathrm{mm}$ 電流 $50 \mathrm{~A}$ の条件で、ガス流量を $20 \mathrm{~L} / \mathrm{min}$ とし、アル ゴンとヘリウムの量を変化させて撮影した結果を示す。ガ ス成分によるプラズマ形状と明るさの差を比較するために 撮影条件はすべて同一としており、ガスの構成比を変化さ せるごとに電極表面を研磨した。アルゴンが主成分の間は アーク形状と電極の明るさにほとんど変化は見られない が、アルゴンの比率が $20 \%$ 以下に下がるとアーク形状が大 きく変化し、電極先端部近傍の㓌極降下部は青く光る領域 に囲まれると同時にアークの発生する領域が不連続的に増 加する。同図 (e) の青色成分のみを表示した図 (j)に見られ るように、青色成分は電極表面とプラズマの境界領域で輝 度が低下しており、電極表面ではなくプラズマ空間で放射 された光だとわかる。電極の明るさも同様にガス成分比に より不連続的に変化している。この図及び顕微鏡写真から 陰極領域の面積を計算し、同一電流密度と仮定して計算し た結果を Fig.6に示す。電流密度は Richardson-Dushmanの 式を用い、電極の仕事関数は $2.9 \mathrm{eV}$ とて計算した。アル ゴンが主成分の場合には電極先端部温度は約 $3,000 \mathrm{~K}$ であ るのに対して、ヘリウムが主成分の場合の電極先端部温度 は 2,500 K から $2,600 \mathrm{~K}$ と低い值となっている。円錐状電極 の先端近傍でアークが発生する場合には、電極内部を通過 する電流密度の増加により電極先端部は効果的に加熱され る。アーク発生領域が円錐状電極の一定程度の面積を占め るようになると、電極を通過する電流密度も低下しジュー ル加熱効果は低下する。純アルゴンシールドの場合にも、 ジュール加熱効果が適切に作用しない例として円錐角を極 端に大きくした太径の電極では先端領域の温度は低下し、 電極全体の温度が上昇する現象が存在する。

Fig.7 に水冷銅板上のアークと軟鋼上のアークを比較し た例を示す。アルゴンとヘリウムの構成比が 1 対 4 の場合 を比較すると、水冷銅板上の場合に比べて軟鋼上のアーク ではカソード領域の面積は若干低下して電極先端部温度は 上昇している。一方、電極自体の明るさは母材が水冷銅板 より軟鋼の場合が明るく、母材から蒸発した金属成分が電 極に衝突して発光する比率が増加したと考えられる。

プラズマの状態には雲囲気圧力が大きく影響する。Fig.8 に雲囲気圧力によりプラズマ形状と電極の明るさがどのよ うに変化するのかを比較した例を示す。小型の圧力チャン バー内に電極と水冷銅板を設置し、真空引き $(0.001 \mathrm{MPa})$ ーアルゴン充填－真空引きーアルゴン充填の予備作業を行 い、チャンバー内部の圧力を $0.005 \mathrm{MPa}$ に設定してアーク

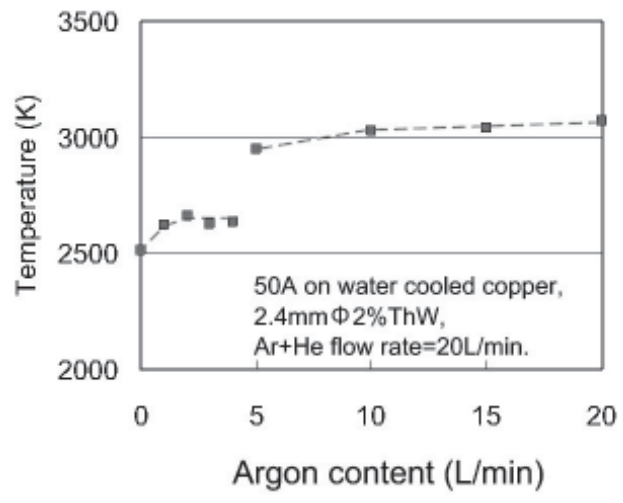

Fig. 6 Effect of gas contents on cathode temperature.

を発生させて実験を行っている6)。アーク電流は $30 \mathrm{~A} 、 50 \mathrm{~A} 、$ $70 \mathrm{~A} 、 100 \mathrm{~A} 、 130 \mathrm{~A}$ の 5 種類の電流值を順次変更して電圧 を測定するとともにアークの写真を CCD ビデオカメラで 連続的に撮影している。所定の圧力で一連の測定を実施し

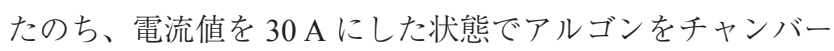
内に所定の圧力に達するまで導入し同様な測定を繰り返し た。大気圧以上では電流值を $100 \mathrm{~A}$ と一定にし、0.4 MPa の圧力になるまで測定を実施した。実験の開始から大気圧 の状態での測定を終了するまでに 30 分以上経過しており、 大気圧に近い状態での電極先端部は溶融に似た状態に变化 している。映像の撮影条件は同一であり、低真空になるほ どプラズマ発光は減少し、0.005 MPa の圧力ではプラズマ はほとんど認識できない状態となる。圧力の減少に伴い衝 突確率が低下し平均自由行程が増加するとともに電離しや すくなるため、イオンはより広範囲に存在できるようにな る。電極は低圧状態の方が明るく撮影され、0.005 MPaで は大気圧下のへリウムアークと類似した映像となる。

Fig.9 は電圧の測定結果を表示したもので、アーク電圧 は $0.05-0.07 \mathrm{MPa}$ で最小となり、この範囲より圧力が高く なるあるいは低くなるとアーク電圧は上昇する7)。撮影し た映像から陰極領域の面積を計算し、その温度を計算した 結果を Fig.10に示す。電極先端部温度は圧力が低いほど 低い值となり、圧力の増加とともに温度も増加する傾向を 示す。大気圧での電極温度が、Fig.6に示した值より約 200 度低く算出されている。この相違については、この実験で の電極先端部が長時間のアーク発生により溶融に近い状態 となっており、電極内の酸化トリウム（以下トリアと記す） が減少しているにもかかわらず両者を同じ仕事関数 (2.9 eV）で計算した結果と考えている。トリア入り電極の仕事 関数値については理論的及び実験的に算出された多くの值 がある ${ }^{8)}$ が、ここでは全体的な傾向を示すために理論值よ りやや高めの值を採用している。 


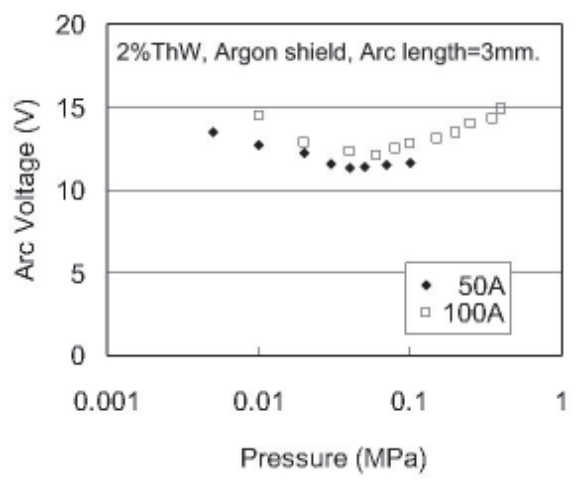

Fig. 9 Effect of pressure on arc voltage.

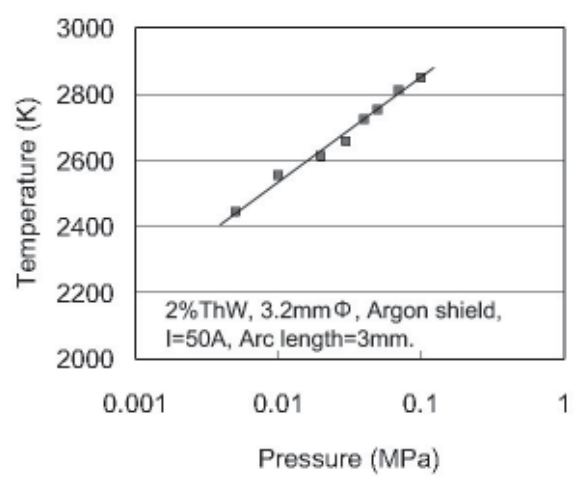

Fig. 10 Effect of pressure on Electrode temperature.

\section{4. 陰極の特徵とその観察}

タングステン電極は溶融温度 $(3,683 \mathrm{~K})$ が高いことから 非消耗電極として多用されている。しかし、酸化タングス テン $\left(\mathrm{W}_{2} \mathrm{O}_{5}\right)$ の溶融温度 $(1,073 \mathrm{~K})$ と蒸発温度 $(1,803 \mathrm{~K})$ が極めて低いことから使用環境によっては電極の消耗が大 きくなる。また、仕事関数を下げて安定にアークを発生さ せるためにトリアなどの仕事関数の低い物質を $2 \%$ 程度含 有させて利用することが多い。トリウム $(2,028 \mathrm{~K})$ とその 酸化物（トリア $=3,593 \mathrm{~K} ）$ の溶融温度はタングステンの溶 融温度より低く、またトリアの蒸発温度 $(4,673 \mathrm{~K})$ は夕ン グステンの蒸発温度（5,933 K）より低いために、アーク放 電の経過とともに㓌極表面からトリアが選択的に減少する ことになる。

Fig.11に高精細 $(1200 \times 1024$ 画素 $)$ ・高深度（12 ビット $=4,096$ 階調）で撮影した酸化雲囲気中のアークの映像と アーク終了後の電極先端部の電子顕微鏡写真を示す。アー ク溶接中の映像は $955 \mathrm{~nm}$ の干渉フィルタを用いて取得し ている。高深度情報を表現するために、12ビットのデータ の下位 8 ビットの情報を青色、上位 8 ビットの情報を緑色、 輝度值の平方根を 256 階調で赤色に対応させる疑似カラー 表示を用いて映像化している ${ }^{6)}$ 。青色の濃淡境界が等輝度 線となっている。電極先端から約 $1 \mathrm{~mm}$ 上方にリムと呼ば

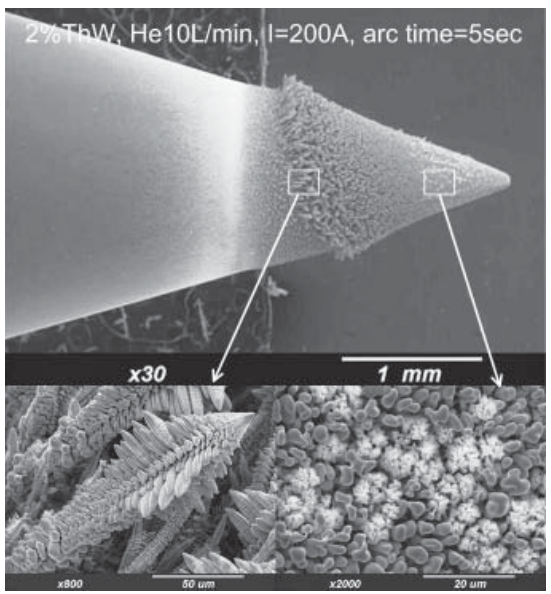

Fig. 12 Erosion of cathode tip.

れるタングステンのデンドライト結晶が成長している。リ ムの左側にアーク写真と等寸の先端部の電子顕微鏡写真、 右上に拡大表示した電子顕微鏡写真を示す。リムのすぐ上 の領域が侵食されて減肉していることが認められる。この 部分が酸化して溶融蒸発し、蒸発した酸化タングステンが 高温のプラズマ空間内で解離される。解離されて単体と なったタングステン原子の蒸発温度 $(5,933 \mathrm{~K})$ はかなり高 いものの、3,000 度弱の電極に衝突すると冷却されて付着し 結晶として成長する。リムの下部はプラズマ自体も高温で あること、電極から電子放出が行われていること、電極表 面近傍で電離・再結合反応が頻繁に行われていることなど から、ガス中の酸素含有量があまり多くない状態では先端 部の侵食はあまり顕著ではない。

Fig.12にヘリウムをシールドガスとして氷冷銅板上に $200 \mathrm{~A}$ のアークを 5 秒間流した後の電極先端部の電子顕 微鏡写真を示す。極めて短時間のアーク通電においても Fig.11に示したアルゴンシールドの電極表面とほぼ同じ位 置にデンドライト結晶の成長が認められ、この結晶成長速 度がかなり速いことが分かる。結晶の形状はシールドガス や電極成分により異なる。電極先端の電子放出領域表面は 微細な侵食がみられる。残存部は微細な樹枝状突起が存在 し、数ミクロンの大きさの突起表面は溶融した後のように 見え、成分分析の結果ではこの領域にはトリアはほとんど 存在していない ${ }^{6)}$ 。1 ミクロン以下の白く表示されている 微細な樹枝状突起表面にはトリアが残存しており、トリア の存在で電子放出が容易なこと、電子放出とトリアの蒸発 過程でこの領域が冷却されることから微細な突起のまま存 在でき、さらに時間が経過しトリアが枯渇すると蒸発潜熱 や電子放出による冷却効果が減少し先端部が溶融して大き な塊になると考えられる。

電極温度が高温の平衡状態に到達した電極表面には母材 の金属成分はほとんど検出できない。母材から蒸発した 金属成分が電極のどの領域まで到達するのかについて検討 
するために、電流 $200 \mathrm{~A}$ で約 1 秒間の短時間アーク放電を SUS304に対して実施した。Fig.13に電極の電子顕微鏡写 真を示す。シールドガスはアルゴンである。眓に示すよう に電極先端から約 $1.3 \mathrm{~mm}$ までの表面領域に母材から蒸発 した鉄とクロムが付着しており、電子放出が盛んな先端か ら約 $0.8 \mathrm{~mm}$ の領域への付着量は、0.8 $\mathrm{mm}$ から $1.3 \mathrm{~mm}$ の領 域への付着量より少ないことが分かる。蒸発した金属成分 の付着が多い領域は、金属イオンが表面に衝突し再結合し て表面に付着したものと考えられ、Fig.12に示したリムが 成長している領域にほぼ対応している。

Fig.14 にアーク発生時間が 10 秒の場合の電極先端部の 映像を示す。この程度の時間が経過すると先端の陰極部で は蒸発が盛んになっており、タングステンのデンドライト 結晶の成長も顕著になってきており、もはや鉄やクロム などの母材成分の付着は明瞭には観察できなくなる。電 極自体の温度も高くなり先端から $2 \mathrm{~mm}$ 以上離れた領域で は、電極内部のトリアが表面へ析出してくる現象も確認で きる。高速度ビデオによる観察では、このトリアが析出し ている領域やデンドライト結晶が成長している領域の現象 も明瞭に観察できるが、カメラの被写界深度の関係で全て の領域の現象を観察するにはもう少し工夫が必要な状況と なっている。同図 (e) に示すように、電極最先端領域では 成分の蒸発が盛んになり、内部への侵食作用も明瞭となっ ている。侵食部の内側の比較的平坦な領域のトリア含有量 は、その内側のミクロポアが多数存在する領域に比較して 極端に減少し、アーク通電時間の経過とともに表面領域の 侵食深さとトリア含有量の少ない平坦な領域が増加してい <。

真空状態の電子放出は、電極表面にトリウムの単原子層 が出現し、低い温度で安定に電子が放出されると説明さ れているが、大気圧アークでは電子放出部表面での蒸発が 顕著となり、実際の表面領域の面積は百倍以上の大きさに なっている。このような状態にもかかわらず、見かけの表 面積とトリウムの仕事関数を用いて算出した温度が説得力 のある数值となっているのが不思議であり、現在高精細か つ高深度な超高速度カメラによる観察でより正確な現象の 把握に努めている状態である。

\section{5. 陽極の特徵とその観察}

陰極では電子放出による冷却作用が存在し、電流密度の 低い場合に、より高温度領域へと電子放出部が不規則に移 動することがある。一方、陽極では電子の衝突による加熱 効果が存在し、比較的安定に陽極点が保持されるが、実際 には、表面の酸化状態や形状と温度分布及び磁界の影響で 不安定な挙動をすることが稀ではない。TIG 溶接の溶け込 みを深くする効果を有する A-TIG 溶接も陽極点の挙動に影 響を与えている。Fig.15に通常の SUS304 上へのへリウム アークと活性フラックスを塗布したSUS304の上へのへリ
ウムアークの比較例を示す。撮影にはND フィルタのみを 用いている。通常のアークでは溶融池表面は比較的安定な 状態に保たれ、溶融池中央部に電極直径の 2 倍弱の明るい 領域が観察される。この明るい領域は母材から蒸発した金 属成分の発光により、斜め上からの映像と側面からの映像 で確認できるようにプラズマの外周部に存在する。母材表 面に活性フラックスを塗布した場合には、溶融池表面には 微細で活発な振動が生じ、溶融池表面の明るく光る領域は 小さくなる。母材表面の中心部からは金属蒸気が勢いよく 噴出しているような青緑色の領域が観察される。通常状態 の青緑色の領域に比較して横幅がせまくなっている。また、 溶融池表面中央部は電極側に盛り上がっている。電流值が $130 \mathrm{~A}$ 以上になると活性フラックスによる深溶け込み効果 が明瞭になるが、溶融池表面は押し下げられ両者の直接的 な観察比較は難しくなる。

アルゴンアークの場合にはプラズマからの発光強度が強 いために溶融池表面の比較が難しくなる。このような場 合には側面から特定波長の映像と電極中心軸上のスペク トル分布映像を同時に取得して比較する手法が有力とな る。Fig.16に活性フラックスの有無によるプラズマ発光状 況の相違を示す。用いたカメラと表示方法は、Fig.3及び Fig.11 と同様である。スペクトル分布は疑似カラー表示の みでは、左図の $950 \mathrm{~nm}$ の映像のように両者の差異を認識す ることが困難となる。このため、右下図に活性フラックス の有無による相違を明示するため、活性フラックスを塗布 している場合の方が輝度の高い画素をその輝度值に応じて 赤色で表示、塗布していない方が輝度の高い画素をその輝 度值に応じて青緑色で表示し、ほとんど大差のない領域は 輝度表示しない映像を示す。この映像から活性フラフラッ クスを塗布していない通常の溶接では溶融池表面での輝度 が高く、電極先端と母材表面の中間距離のところでほぼ同 じ輝度となり、電極側では活性フラックスを塗布した場合 の輝度が高くなることが分かる。ただ、約 $600 \mathrm{~nm} の ア ~$ ルゴン特性スペクトルのみは、フラックスを塗布した場合 の方が全空間領域で輝度が高くなるという結果が得られて いる。

Fig.17に通常の母材領域から活性フラックスを塗布し た領域へと連続的に溶接している状況を高速度カメラで取 得した例を示す。上図は溶接進行方向前面から撮影し、電 極中心軸上の輝度を時間軸方向に展開して表示した例であ り、活性フラックスの効果が明瞭になるにつれて明るく光 る領域が溶接線後方へと後退していき、最終的には極めて 狭い領域に収束しその位置が時間的に変動する様子が理解 できる。下段の図は異なるメーカーの高速度カメラにより 側面から情況を撮影した例であり、活性フラックスを塗布 した領域にはいると金属蒸気による発光が小さくなり、溶 融池長さが長くなるとともに電極中心から溶融池前面まで の距離が短くなることが分かる。活性フラックスの無い通 
常の状態では溶融池表面は比較的安定で振動が少ないのに 対して、活性フラックスを塗布した領域では溶融池表面に は微細で高速度の振動が発生している。活性フラックスが 溶け込みを深くする理由については、多くの説が立てられ ているが2)、活性フラックスが効果を有するには、活性フ ラックスの成分が (1) 溶融池表面に浸透すること、(2) 溶融 金属内部に浸透すること、(3) プラズマ内部に浸透すること、 のいずれかが成立しないと物理的な変化は生じない。高速 度ビデオによる観察結果からは、少なくとも活性フラック スの一部は溶融し溶融池表面に浸透すること、アノード領 域は狭められることは理解できる。

Fig.18に活性フラックスが溶接ビード外観に与える影響 の例を示す。上図は通常では母材表面が溶融しない条件で アークを発生させ、フラックスを塗布した領域で母材が溶 融し、フラックスが枯渇するとまた表面が溶融しなくなる 例を示している。下図はへリウムシールドで溶融池が確実 に生成する状況でビード幅とスマット発生に及ぼす活性フ ラックスの効果を示す。活性フラックスを塗布している状 態では金属蒸気の発生は抑制され母材表面へのスマットの 付着は少ない。活性フラックスを塗布した領域を通過し、 溶融池内部のフラックスも枯渇した状態になると、ビード 幅が広がるとともにビード周辺へのスマット付着量が急激 に増加している。アークスタート時の高速度ビデオの映像 でも、活性フラックスを塗布した表面でのアークスタート の場合には瞬時に母材から強いプルームが発生し、アーク が安定に発生する。一方、フラックスを塗布していない場 合には、母材表面で極点が不規則に移動し安定なアークに 移行するまでに時間がかかる場合が多く観察されている。 塗布されたフラックスは母材表面とは熱的に遮断されてい るのに等しい状況であり、熱容量が小さく導電性のあるフ ラックスが瞬時に蒸発しプラズマ内部で電離することによ り安定にアークが開始されると解釈できる。

以上示してきたように溶接では利用する溶接手法やシー ルドガスに起因する強度の高い離散的な波長成分の光と それより低い連続波長の光が放射されている。最近では特 定の波長帯のみを透過させる干渉フィルタあるいは特定の 波長帯をブロックするノッチフィルタが容易に入手できる ようになっている。また、特定波長のレーザ光源も安価に 市販されている。撮影目的に応じてこれらを適切に選定す ることにより想像以上の画質の映像が取得可能となってい る。Fig.19にレーザ照明を用いたアルゴンアークの映像例 を示す。レーザの波長は $532 \mathrm{~nm}$ の緑色であり、取得した 映像の緑色部分のみを白黒で表示してある。上図はレーザ が照射されている時の映像、下図はレーザが照射されてい ない時の映像である。照明の無い場合には周辺の状況が理 解できないのに対し、レーザ照明を適切に選定すれば母材 表面と溶融池の判別及び溶融池表面に存在するスラグや金 属蒸気などが明瞭に識別できる。

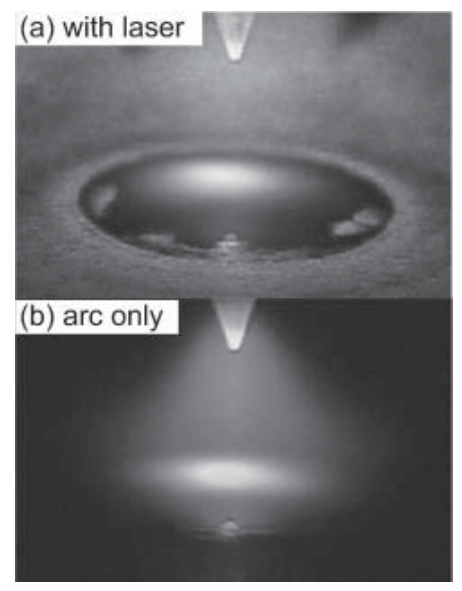

Fig. 19 Effect of laser illumination on arc image.

\section{6. 結 論}

本解説では、溶接現象を可視化するための基礎的な知識 としてプラズマの特性及び㓌極と陽極表面の反応を中心 に、論文などでは見る機会の少ない映像を用いて紹介した。 可視化では高精細化と高速度化により取り扱うべきデータ 量が膨大となっているのが現状であり、これらのデータ処 理手法が重要な課題となっているが紙面の都合で割愛し た。

\section{引用文献}

1) Y.Ogawa: Science and Technology of Welding and Joining, 16-1 (2011), 16-27.

2) M.Tanaka et al.: Welding International, 19(2005), 870-876.

3) 山村学、村山精一: “プラズマの分光計測”、学会出版センター、 (1995), 89-94.

4) Y.Ogawa: Proc. 3rd ISOPE, 4 (1993), pp.424-428.

5) Y.Ogawa: Proc. 12th OMAE, 3-A (1993), pp.424-430.

6) Y.Ogawa et al.: "Arc Behavior under Extreme Condition", TRANSTECH PUBLICATIONS, 54105 (2003), pp.4110-4416.

7) Y.Ogawa et al.: Proc. 14th ISOPE, 4-YS01 (2004), pp.1-8.

8) M.Tanaka et al.: J. Phys. D:Appl.Phys. 38 (2005), 29. 
溶接現象の可視化技術（小川）

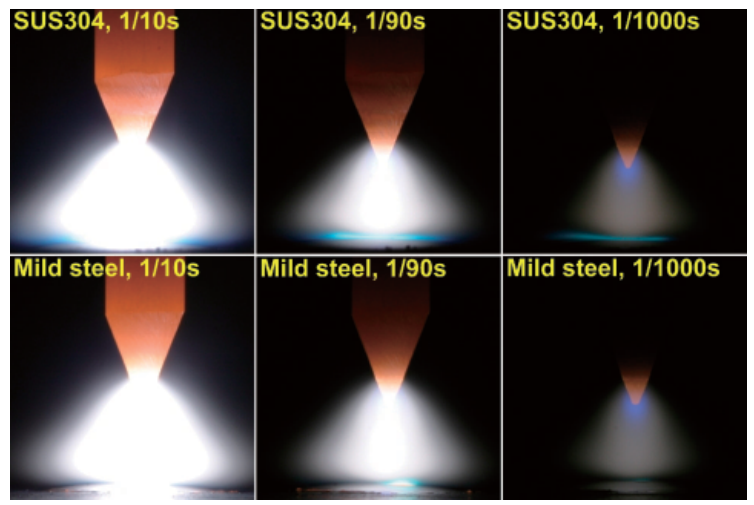

Fig. 1 Example of argon arc.

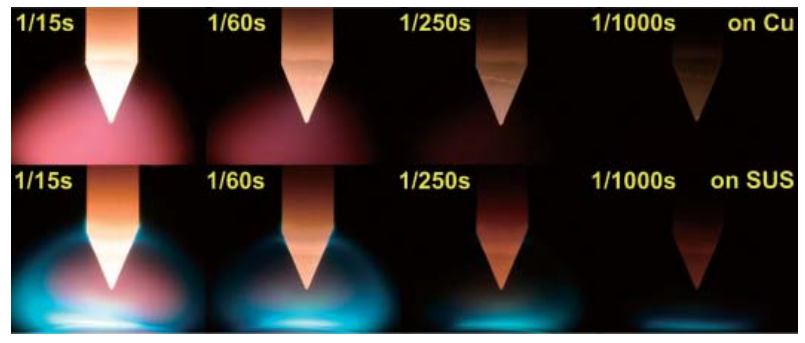

Fig. 2 Effect of metal ion on arc plasma condition.

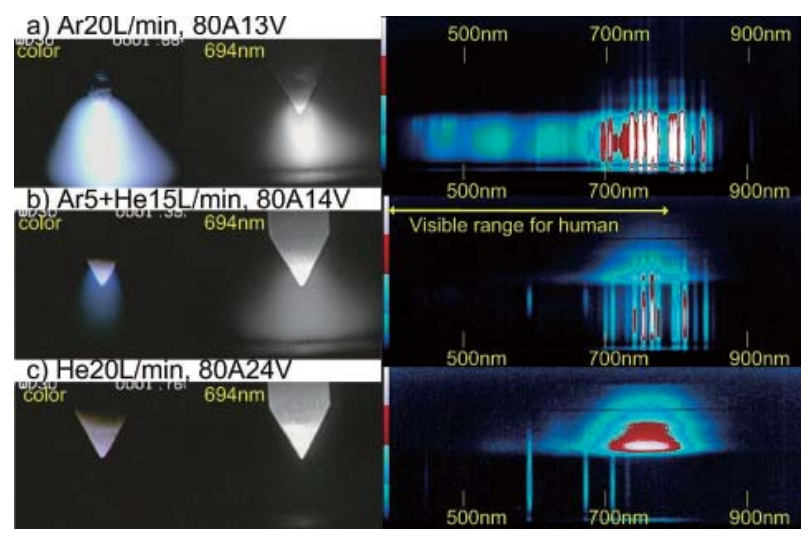

Fig. 3 Effect of gas contents on arc plasma condition.

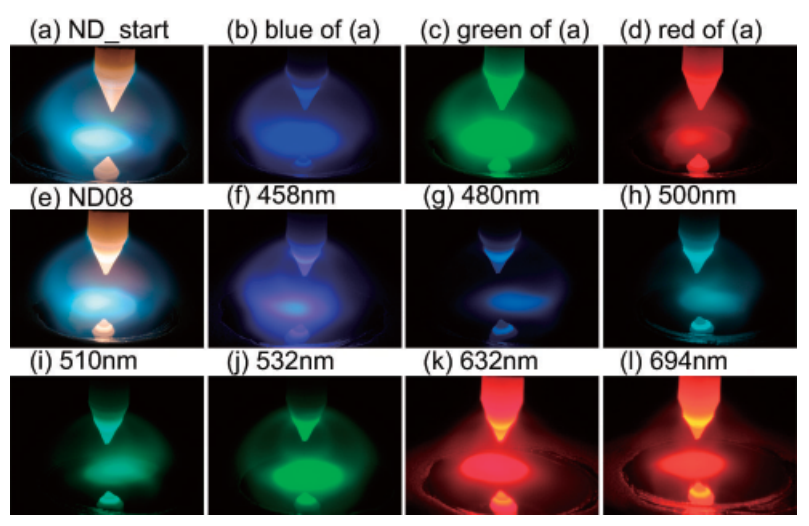

Fig. 4 Example of single color images.

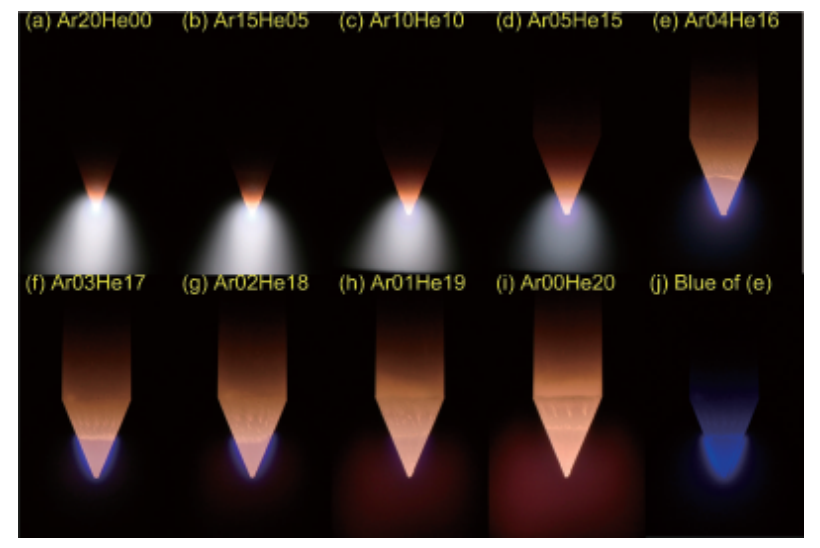

Fig. 5 Effect of gas content on arc images.

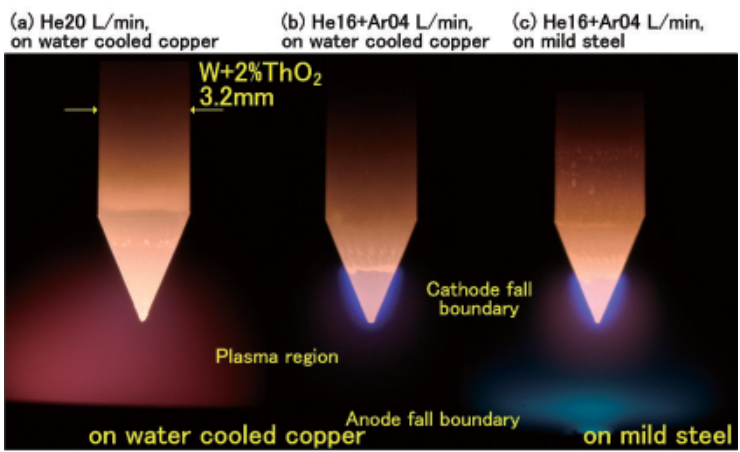

Fig. 7 Typical arc shape on SUS304.

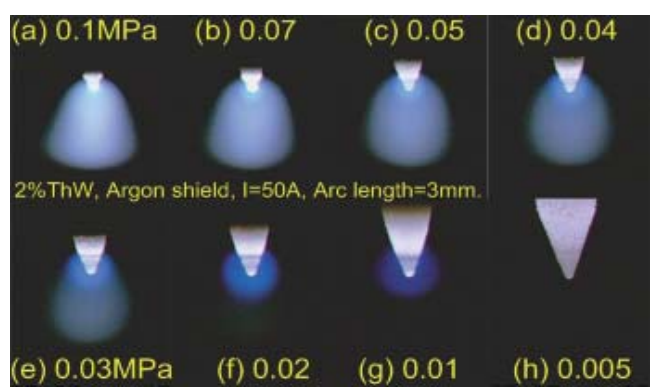

Fig. 8 Arc images of cathode at $100 \mathrm{~A}$ in pure argon in various pressures.

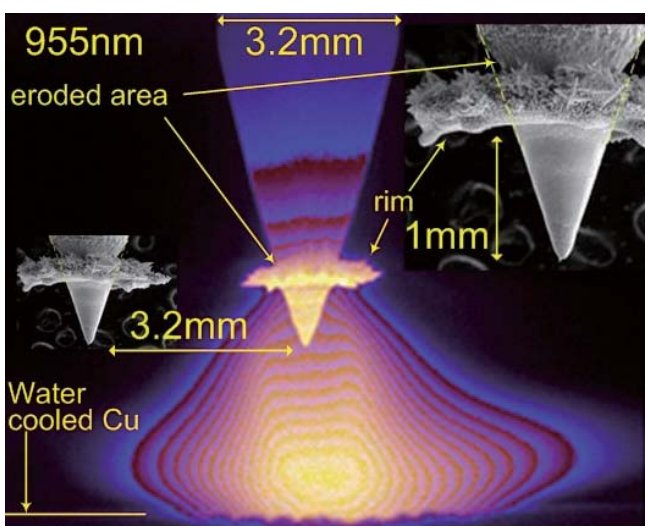

Fig. 11 Generation of RIM on cathode tip. 


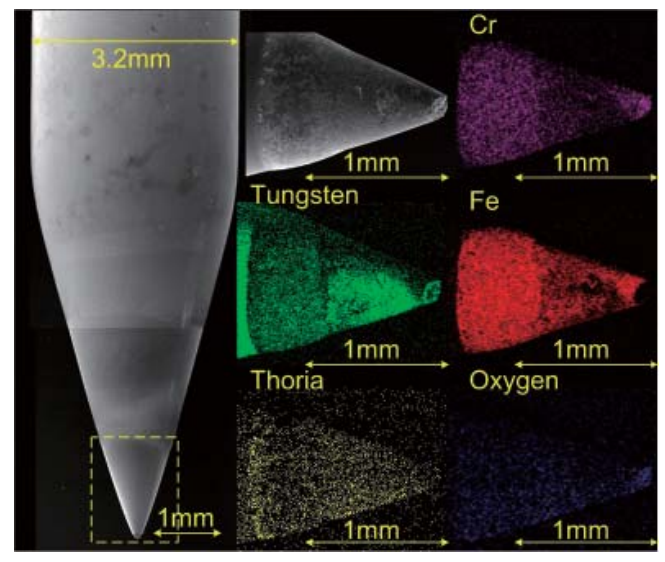

Fig. 13 Contamination of cathode tip.

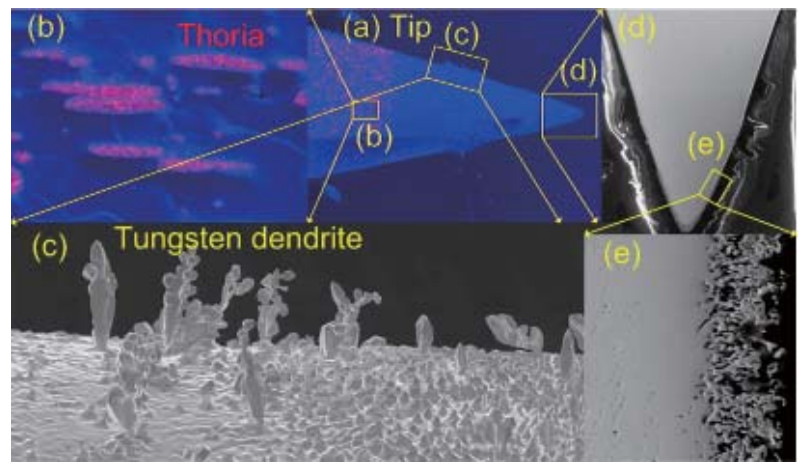

Fig. 14 Erosion of cathode tip.

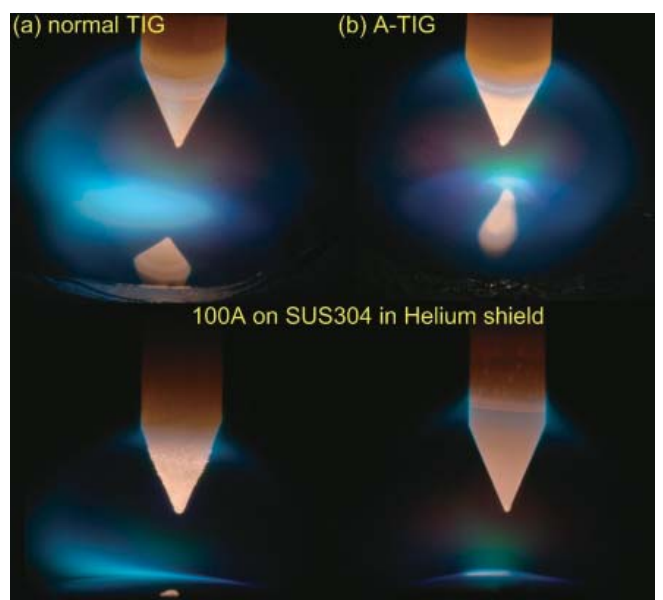

Fig. 15 Effect of active flux on arc shape.

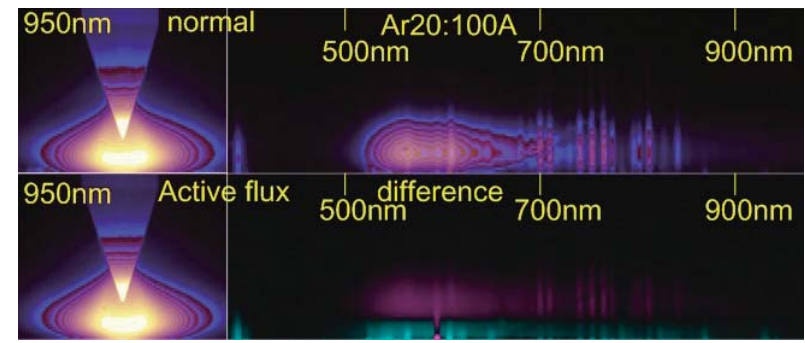

Fig. 16 Spectroscopic characteristics of active flux.

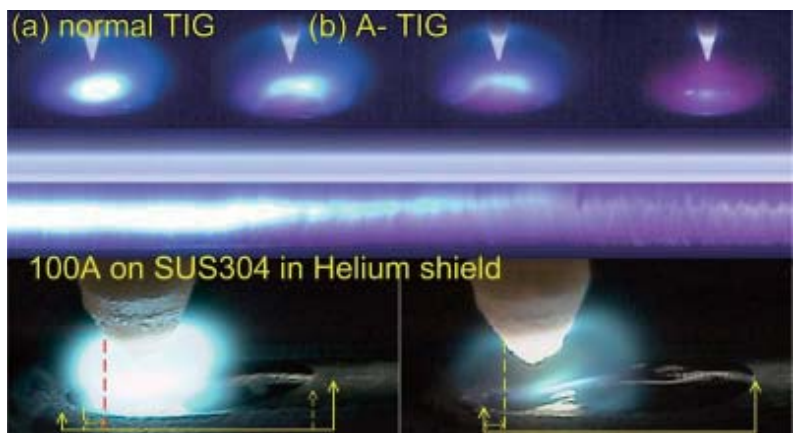

Fig. 17 change of arc profile by active flux.

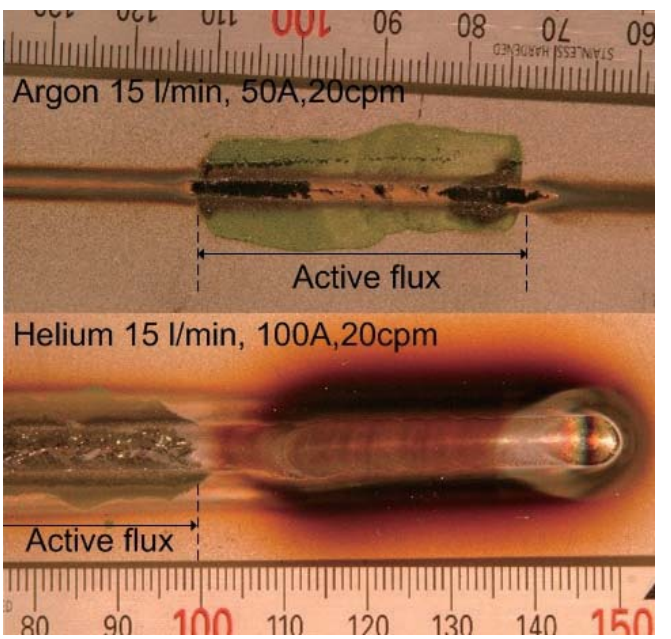

Fig. 18 Effect of active flux on bead appearance. 